\title{
Impact of Transaction for Institutional and Non-Institutional Persons for Rising Magnet Effect on Price Limit at Tehran Stock Exchange
}

\author{
Mir Feiz Falah Shams ${ }^{1}$, Meysam Ali Mohammadi ${ }^{2}$, Hamidreza Kordlouie ${ }^{3}$ \& Hamid Mahdavirad ${ }^{4}$ \\ ${ }^{1}$ Business Faculty, Tehran Central Branch, Islamic Azad University, Tehran, Iran \\ ${ }^{2}$ Finance Department, University of Economic Sciences, Tehran, Iran \\ ${ }^{3}$ Finance Department, Faculty of Accounting and Management, Eslamshahr Branch, Islamic Azad University, \\ Tehran, Iran \\ ${ }^{4}$ Faculty of Economics and Management, Science and Researches Branch, Islamic Azad University, Tehran, Iran \\ Correspondence: Hamidreza Kordlouie, Finance Department, Faculty of Accounting and Management, Islamic \\ Azad University, EIslamshahr Branch, Tehran, Iran. Tel: 98-912-513-2200. E-mail: \\ hamidreza.kordlouie@gmail.com
}

Received: January 13, 2014

Accepted: January 24, 2014

Online Published: March 25, 2014

doi: 10.5539/ijef.v6n4p276

URL: http://dx.doi.org/10.5539/ijef.v6n4p276

\begin{abstract}
At many stock exchanges of world, it is applied from price limit for different purposes including: reducing frequency and manipulation of stock. One of the most important effects of price limit is magnet effect that is available in most of stock exchanges of world. The magnet effect on Tehran stock exchange is proved and in this article we decide to study this effect on Tehran stock exchange and role of active investors at stock market. Studies on 24 companies as case study including: Kesaveh, Ghalrest, Shomal Excavation, Betras, Khazamia, Khasapa, Sefars, Sina, Fazer, Fasmin, Ghapira, Ghanisha, Kermasha, Koravi, Vitro, Sapa, Sakht, Sepah, Sandogh, Lesapa, Melat and Madan reveal that except one case (Gheshkar) in all of the companies the role of institutional investors on magnet effect is higher than non-institutional investors.
\end{abstract}

Keywords: price limit, magnet effect, institutional investors, non-institutional investors, stock exchange

\section{Introduction}

Stock exchange of each country reveals complete competitive market; since, number of buyers and sellers is very high, the goods are homogenous, information is available to public and finally price is determined by market activists based on supply and demand mechanism. One of the most important purposes of establishing stock exchange is creating clear mechanism in contrast of supply and demand for determining price of financial assets. Within financial markets designers and legislators attempt to solve the available impediments of supply and demand; since, in this way the price of financial assets is more close to their innate value which reveals important property of effective market i.e. determined price in market is regarded as suitable index for real value of stock exchange. Within newly established markets having rules and regulations that prevent from supply and demand is more obvious. One of the most important rules in newly established markets is price limit that is regarded as control factor against frequency of stock price and in order to reduce market frequency, price manipulation and loss of investors due to emotional decisions. Price limit is nearly maximum and minimum price for each stock on a daily work and price only moves within this limit (price limit for price frequency). At website of Tehran stock exchange the term price limit means price limit of changes in price. Establishing this price limit goes back to early 1990's. It is to be noted that there are many challenges in the field of policy making and legislation to control frequency of financial markets by using price limit of price frequency. Meanwhile, in spite of performing this research no equal result is obtained from studies, rather some researches refer to necessity of applying price limit of stock and its positive effects. On the other hand, other researches refer to negative effects of applying price limit and necessity of increasing price limit or eliminating limit; meanwhile, in most of countries the price of stock was increased along with time and simultaneous with growth of financial markets. Applying price price limit has some advantages and disadvantages. Its advantages are including: reducing market frequency, protection of investors, prevention of financial crisis, maintaining market and reducing manipulation. Its disadvantages are including: delay in finding out price, excess reaction, intervention 
at transaction, facilitation of frequency and magnet effect. Many researches are performed in this field and some of them confirm its effectiveness and the others confirm its ineffectiveness.

\subsection{Theoretical Basis \& Research Background}

The necessity of effectiveness at stock market is having free competition and on the other hand supply and demand leads to finding out price that is clearer to real value of securities. Consequently, stock markets should be free from any limitation versus supply and demand. Meanwhile, in some stock exchanges the policymakers and legislators enact many rules in order to protect from benefits of investors against severe frequency of stock price. Severe frequency in stock price is generally due to imbalance at supply and demand or speculates transactions; therefore, generally in markets with absence of market makers and specialists in order to direct the price of stock, generally severe price limit is happened (Safar, 2012). In many stock exchanges of world including: Taiwan, Thailand, Australia, Spain, Malaysia, Italy, Turkey, France, Korea, Japan and Iran legislators in order to reduce frequency of market and risk and loss of investors due to making emotional decisions, enact price frequency i.e. price of stock on each working day moves toward a definite limit. In Iran since the year 2008 until now there was price price limit in price of stock. In fact, applying price price limit for price of stock has some advantages and disadvantages. Its advantage is reducing frequency of market, prevention from playing with price by great shareholders and investors and prevention from manipulation of prices.

\subsection{Definition of Trading Halt}

During recent 2 decades the trading halt phenomenon of a specific stock is turned into a common process among many international stock markets, for example, at stock exchange of New York the symbol for 4 ordinary stocks is halt daily. Legislators halt a trading of a stock for maintaining stability and discipline of market in order to protect from advantages of investors. Generally stock exchange halt trades in order to protect from uninformed traders or market makers against asymmetrical information that impose considerable trading costs. In fact, trading halt is temporary halt at specific official transactions or total market. Supervision authorities of market apply from this mechanism in order to offer more opportunities for investors to assess the new information offered about a specific company. In addition, this mechanism is applied for enforcing companies to disclose new information. Trading halt is a common mechanism that is broadly applied at different stock exchanges. The main purpose of trading halt is offering required opportunities to investors for showing reaction toward new information so that through making orders and upon analysis, the new information enters into system and price of stock is reached to balance level. Therefore, the purpose of trading halt is being certain of fair access of all investors to information at the time of entering new information or considerable changes. Recep Bildik and Selim Elekkdag (2005) studied trading halt at stock exchange of Turkey. According to the available data for each transaction he evaluated the efficiency of trading halt through studying return behavior by price limit and size of transaction published related information. Findings of Bildik et al. showed that much new information is published upon 15 minutes opening of transactions in prices. Reaction of investors toward bad news (negative) in comparison to their reaction toward positive news (good) is more severe. In addition, results of research by Bildik in relation to effects and duration of halt is strongly confirmed. Bildik et al. believed that mechanism of obtaining to real price, lack of having exclusive market, mechanism of group opening and limitation in relation to elimination of orders during trading halt leads to facilitating in balanced price during halt period. Bildik et al. concluded that in spite of trading halt and publishing new information, the legal investors obtain more benefit than real investors through selecting more suitable time for transaction after the halt period. Legal investors near to halt time perform systematic buy and sale with better prices in comparison to real investors. Finally, Bildik et al. concluded that trading halt was effective for publishing information and play key role for improving mechanism of obtaining to real price.

\subsection{Definition of Price Limit}

Price limit is maximum or minimum change in price price of stock in a day so that performing transaction out of determined limit is impossible daily (Eskandari, 2011). According to another definition, price limit is a limit that is created by market makers so that price limit for securities during one day is limited (Bildik \& Elekdag, 2002). In addition price limit is from the lowest price to maximum price that may have frequency during several official stock exchange trades (by-law of transactions at Tehran stock exchange approved by Subsidiary Commission of Higher Commission of Stock Exchange, January 22, 2007). Price limit has 2 properties that control frequency of stock price including:

1) Creation of legal limitation (impediment) in change at price stock;

2) Creation of a time for logical reassessment of stock; 
It seems that price limit prevents from reducing prices, severe frequency in price and creates time period for revision and reassessment. Effect of this property is completely obvious at turbulence market. When there is turbulence market generally investors are influenced by mental atmosphere of market and make illogical decisions and even show excess reaction. Making such hurry decisions is more common among individual investors and there is probability of incurring loss by these investors while turbulence of market is very high. Testler in the year 1981 in his research concluded that price limit under market turbulence creates more time for counseling and reassessing to investors. Many researchers believe that turbulent behavior is effective on increasing frequency that lead to financial crisis at Oct. 1987 and therefore it is recommended to apply from price limit at financial markets. These researchers believe that price limit prevents from price freefall at crisis in the year 1987 which leads to relaxing turbulent traders and effective on reducing crisis.

Table 1. Limit of price limit for some countries of world

\begin{tabular}{lccccc}
\hline Country & $\begin{array}{c}\text { Percentage for } \\
\text { limit of frequency }\end{array}$ & Country & $\begin{array}{c}\text { Percentage for } \\
\text { limit of frequency }\end{array}$ & Country & $\begin{array}{c}\text { Percentage for } \\
\text { limit of frequency }\end{array}$ \\
\hline Argentina & 10 & Austria & 5 & Ireland & None \\
Belgium & 5 to 10 & Ecuador & 15 & Mexico & 10 \\
Egypt & 5 & Finland & 15 & Iran & 4 \\
Malaysia & 30 & Pakistan & 7 & Germany & None \\
Philippine & 40 to 50 & India & 8 & U.S.A & None \\
France & 10 to 20 & Turkey & 5 & Greece & None \\
Japan & 10 to 60 & Portugal & 15 & Brazil & None \\
Thailand & 30 & Spain & 10 & England & None \\
\hline
\end{tabular}

As it was already mentioned, the price limit has some advantages and disadvantages including:

1) Delayed price discovery: It means prices on day are not able to show great reaction toward published information; therefore, the day price of stock is not is real price (Fama, 1989; Lehmann, 1989; Lee et al., 1994).

2) Trading interference: It means lack of rising real price of stock on day.

3) Volatility spillover: It means volatile prices due to reaching to price limit is halted and on next working day it is observed as additional turbulence (Kuhn et al., 1991; Kim \& Rhee ,1997; Kim, 2001).

4) Magnet effect: It means prices when approaching to price limit are absorbed i.e., through approaching to price one of the limits (minimum or maximum) is increased. Magnet effect means if the distance of price with price limit is near to zero, the probability of reaching price limit is higher. The most theoretical study that was performed about relationship of magnet effect was by subrahmanyam which mentions that at stock exchange that transaction are halted due to reaching to price limit, which refers that stock exchanges that are halted due to reaching to price limit, in case of reaching to adjacent limit the market makers demand to maintain their stock liquidity ability, changes in price of stock is increased and the probability of approaching price of stock to price limit is increased i.e., subrahmanyam through his theoretical study concluded that price limit creates magnet effect and changes and frequency of prices is increased and on the other hand size of stock transactions is increased. Chan et al. (2005) by using information of transactions at KLSE stock concluded that there is this effect. They found out that having price limit do not assist to asymmetrical information and creates costs that are observed at stock exchanges with price limit. Du et al. (2005) studied information of transaction at KSE stock of Korea and concluded that small price limit create more severe magnet effect. They studied magnet effect for 5 microstructures including: return rate, volume of transactions, frequencies, order process and type of order. In their study they found out 2 conclusions: firstly, there is vice versa relationship between authorize price limit and magnet effect within 5 aforesaid variables i.e. if level of price limit is higher, the level of magnet effect is less and vice versa. Secondly, within high limit the volume of transaction for investors and speed of frequency is increased due to 2 main reasons including: psychological reason of investors and lack of installments basis sale at stock exchange of Korea. The final result is that the magnet effect is available at price limit of stock exchange. In addition, in this study it is observed that when price is approached to price limit, the investors change their transaction behavior to have more safe orders i.e., through increasing price the volume of purchase is increased and through reducing price the investors hold considerable volume of market sale. Du et al. (2005) in his study stated that it is required to observe difference between momentum effect and magnet effect. Although discrimination between these 2 items is very different, they recognized different theories. Through offering 
unreal price limit (quasi price limit) and observing traded prices and volume of transactions with duration at price of stock was gone under quasi frequency and comparing it when price of stock was free from quasi price limit, they discriminated between momentum effect and magnet effect. They believed that when distance for volume of transaction and price limit of stock is equal the observed effect is called momentum effect; otherwise, it is called magnet effect. Findings of Hsieh et al. (2009) by using Logit model (a correlation model for estimating probability of occurrence an event affiliated to set of independent variables). The Logit model is established for analyzing variables having 2 assumed modes. The model of this article is executed for difference distance of price limit and it was determined that at which distance of price limit the magnet effect begins. This model shows that when magnet effect begins the price distance until top price limit is less than 9 ticks and may even reach to minimum price limit of 4 ticks. Hsieh referred to some advantages of this model including:

1) By using different models we obtain equal results, for example model of Prabit offers equal results with Logit model

2) In this research one of the most active stock exchanges of world is stock exchange of Taiwan in order to study magnet effect; therefore, in this research the error due to low transaction is not appeared

3) All of the companies stock exchange of Taiwan we studied which this issue eliminates error of selecting case study in relation to magnet effect

4) In this research all transactions close to price limit were studied and it was not limited to transactions ending to price limit

David et al. performed one of the most important studies in relation to magnet effect. Their study was performed on Jan. 3, 1998 until Mar. 20, 1999 that was 324 days in sum. At stock exchange of Taiwan 4.7\% cases had transactions higher than price limit and $3.7 \%$ of transactions were lower than price limit. Through their study they observed considerable magnet effect at higher level of price limit and did not reported considerable magnet effect at low price limit. They studied 5 minutes return at stock exchange of Taiwan. Cho et al. selected 345 Taiwanese companies that had one transaction at 5 minutes and then by using self-correlation method they studied magnet effect. Coefficients of variables of model show that strong magnet effect at high price limit and poor magnet effect at low price limit 90 stocks from S\&P 500 stock exchange. In this study the magnet effect for stock of S\&P 500 stock exchange was not observed and the interesting point is that at these stocks there was negative magnet effect at low level of price limit. David et al. also applied from another method other than correlation in order to show the magnet effect. This method is based on strategy of establishing portfolio, buy and sale stock at define time. On this basis, when price of a stock reaches to $4 \%$ from $7 \%$ the price limit is positive, that stock is purchased and is sold on next day. In addition, when price of a stock reaches to $-4 \%$ from $-7 \%$ the price limit is negative and the stock is sold on installment basis and on the beginning of next working day the account for that stock is closed. If there is magnet effect, when price of a stock reaches to $4 \%$ over price limit by high probability it reaches to upper limit of price limit and in this way the transaction strategy is profit making. Therefore, in relation to low limit of price limit in case of having magnet effect, if price reduces to $4 \%$ lower than price limit, by high probability it reaches to lower price limit and investment strategy is profit making. There are studies that reject this effect. For example Abad and Pascucal 2007 through studying stock exchange of Spain (SSE) did not find evidences for existence of magnet effect. In addition, Kuserk et al. through studying contracts of bonds for treasury did not find magnet effect. Tooma Eskandar 2011 stated that magnet effect is only available at stock market and empirical studies performed at bonds market did not show magnet effect which is due to existence of lever and logical transactions. Tooma studied data for stock market of Egypt from Jan. 3, 1994 until Dec. 31, 2001. In Egypt market there was 5\% price limit from the year 1997 until 2002 that transactions through reaching to these prices were halted. Therefore, in the first half of time period of this study there was no price limit, meanwhile, at second half there was price limit in market. In the period that was price limit on $8 \%$ of days the prices reached to price limit. It is to be noted that this is the only study that examines magnet effect with either existence of non-existence of price limit and therefore it is concluded that applying price limit leads to magnet effect. In this study it was applied from Logit model that proves existence of magnet effect in Egypt market. The sample of this study was 5 companies at stock exchange of Egypt that forms 12\% total volume of transactions for stock exchange of Egypt. Tooma through prices at beginning and closing stock and by using Logit model observed that the probability of reaching price of stock to price limit when there is price limit is more than times when there is no price limit. He also tested this effect with Prabit model and obtained equal results. In addition in order to extend his claim concerning to existence of magnet effect at Egypt market, repeated calculations for all companies at stock market of Egypt and obtained equal results. Mohammad Alavian Ghavanini 2011 in his thesis by supervisor of Dr. Shiva Zamani under title of "studying magnet effect on price limit at Tehran stock exchange" examined one of the consequences of price limit called magnet effect and 
in continuation studied existence or non-existence of magnet effect by statistical self-correlation model with highly transaction stocks (Shomal Excavation Co, Telecommunication Co, Sina Bank, Iran Marine Industries and Saipa Co) that holds $23 \%$ transactions at Tehran stock exchange in the year 2009 and concluded that stock of these companies has negative magnet effect on their price limit. It is to be noted that lower limit are more dependable than higher limit and also it is observed that momentum effect is different with magnet effect.

\subsection{Research Hypothesis}

The effect of transaction for non-institutional investors for rising magnet effect of stock price toward price limit is more than transactions of institutional investors

\section{Research Methodology}

The present research methodology is descriptive-correlation based on analysis of time series data and with respect to objective it is applied research. Tests and data analysis are performed based on regression model by using Eviews 7 software. Statistical universe of this study is all companies listed at Tehran stock exchange from Mar. 20, 2012. The statistical sample is selected by non-random separation method so that results have enough validity. In this research through applying set of criterions the following sub-sample is selected:

* There is transaction at minimum $70 \%$ of period

* Level of frequency of market is nearly high

* The volume of transactions of selected companies should be high

In this research the samples of thesis with title of "studying magnet effect on existence of price limit at Tehran stock exchange" that was defended by Mr. Mohammad Alavian Ghavanini were selected by using aforesaid 3 variables.

\subsection{Research Variables \& Its Assessment}

Research data consists of 5 minutes time series transacted at stock exchange that were extracted from Tehran Stock Exchange Technology Management and also was benefit from capital of company that this variable was collected from Website of Stock Exchange Company. Variables of this research are divided into 2 classes including: dependant and independent

\subsubsection{Dependant Variable}

Dependant variable is regarded as type of variable that is either observed or measured and its influence on independent variable is determined. In this research the variance for return of 5 minutes time series shows frequency of stock price that was selected as dependant variable. In order to calculate return from stock it is applied from the following formula:

$$
R_{t}=\operatorname{Ln}\left(p_{t} / p_{t-1}\right)
$$

$\mathrm{R} 1$ is return for price of each stock at desired time series that in our research we obtained total return during 5 minutes that was standardized with Garch model and then the standard return within range of (+-2) the standard return for final prices of yesterday is separated and is deducted from total return in the first section

\subsubsection{Independent Variable}

Independent variable is a variable that by using it the dependant variable is described or anticipated and researcher intends to measure the influence or relationship between this variable with dependant variable. The variable for size of company is regarded as independent variable of this research that is regarded as control variable. For size of company it is applied from normal logarithm of stock at stock price. 


\subsection{Descriptive Variables of Research}

Table 2. Descriptive variables

\begin{tabular}{lc}
\hline Name of Variable & Calculation \\
\hline Return rate & $R_{t}=\operatorname{Ln}\left(p_{t} / p_{t-1}\right)$ \\
Standard return rate & $z_{i, t}=\frac{u_{i, t}}{h_{i, t}^{\frac{1}{2}}}$ \\
& $m_{t}=N^{-1} \sum_{z_{i, k Q}} z_{i, t}$ \\
Average return rate before quasi frequency & $\left(z_{i, t}-m_{t}\right)$ \\
Conditional variance for times series of 5 minutes & $M V=L N\left(s^{*} p\right)$ \\
Normal logarithm for size of company &
\end{tabular}

\subsection{Conceptual Methodology \& Model of Research}

According to the aforesaid descriptions the following model is offered for research

$$
\left(z_{i, t}-m_{t}\right)=\mu_{B S} I_{B S}+\mu_{B} I_{B}+\mu_{S} I_{S}+\mu I+\gamma M V_{i}+e_{i, t}
$$

In this model $z_{i, j}$ is standardized return based on GARCH; therefore, by using 5 minutes time series for transaction of each stock, a AR model is created as follows:

$$
r_{i, t}=\mu_{i}+a_{i, 1} r_{i, t-1}+a_{i, 2} r_{i, t-2}+\ldots \ldots .+a_{i, p} r_{i, t-p}+u_{i, t}
$$

In next step according to post-events of self-regression model or AR model a model of GARCH (q,p) is extracted for determining imbalance of condition for return days in order to extract zi,j

$$
h_{i, t}=\alpha_{i, 0}+\alpha_{i, 1} u_{i, t-1}^{2}+\alpha_{i, 2} u_{i, t-2}^{2}+\ldots+a_{i, q} u^{2}{ }_{i, t-q}+\beta_{i, 1} h_{i, t-1}+\beta_{i, 2} h_{i, t-2}+\ldots+\beta_{i, p} h_{i, t-p}
$$

MV is normal logarithm for size of company that this variable is control variable and neutralizes approaching return to high level and low level for size of company, $\mu$ is magnet effect that if it is zero it means that there is no magnet effect and if it is not zero it means that there is magnet effect. If $\mu$ is larger than zero the magnet effect is positive (positive self-correlation) and if it is negative it means that magnet effect is negative. This model is calculated for frequencies of top limit and low limit and in this way it is determined the status of magnet effect toward top limit and low limit of frequency and what is speed of magnet effect at top limit and low limit. Whereas at Iran stock exchange the percentage of floating stock is very low and most of stocks (near to $75 \%$ ) is blocked by institution; therefore, we select the variable of $75 \%$ for separating transaction of institutional and non-institutional persons. It is to be noted that in order to benefit from this percentage, we benefit from comment of financial experts (managing director of stock broker companies).

$$
\begin{gathered}
I_{B S}=1 \text { if } R_{i, t}{ }^{S} \geq . / 75, R^{B}{ }_{i, t} \geq . / 75 \\
I_{B}=1 \text { if } R^{B}{ }_{i, t} \geq . / 75, R_{i, t} \prec . / 75 \\
I_{S}=1 \text { if } R^{B_{i, t}} \prec . / 75, R_{i, t}{ }^{S} \geq . / 75 \\
I=1 \text { if } R^{B}{ }_{i, t} \prec . / 75, R_{i, t}^{S} \prec . / 75
\end{gathered}
$$

In which $\mathrm{R}_{\mathrm{ij}}^{\mathrm{B}}$ is ratio for volume of purchase at stock $i$ at the time $\mathrm{t}$ toward institution of total volume of purchase and $\mathrm{R}^{\mathrm{S}} \mathrm{ij}$ is ratio for volume of sale at stock $\mathrm{i}$ at the time of $\mathrm{t}$ toward institution of total volume of purchase.

By using $\mu$ coefficients obtained from the aforesaid regression, we find out whether there is magnet effect by institutional or non-institutional investors or not. If each of the coefficients related to $1(\mu)$ is significant, it refers to existence of magnet effect through the same class of investors. For example, when $\mu$ related to 1 is significant it shows that magnet effect is created by non-institutional investors.

\subsection{Estimating ARMA Model (Kesaveh Company)}

In this research by using Box Genkis method and estimating AR and MA models and by assistance of Eviews 7 software, it is recommended that ARMA (3) model according to different criterions such as: AIC, SBIC, HQIC and $\mathrm{R} 2$ are the most suitable models; since, AIC, SBIC and HQIC are the lowest level and the highest level is R2. The ARMA model is offered as: 


$$
R_{t}=c(1)+c(2) R_{t-1}+c(3) R_{t-2}+c(4) R_{t-3}+e_{t}
$$

$\mathrm{C} 1$ is fixed member of model, $\mathrm{R} 1$ equals to level of return at time t, Rt-1 equals to level of return at time t-1 and R1-2 equals to level of return at time t-2 and R1-3 equals to level of return at time t-3 and waste at time $t$.

Table 3. Results of estimating ARMA model (Kesaveh Co)

\begin{tabular}{ccccc}
\hline Variable & Coefficient & Standard Deviation & T statistics & Probability \\
\hline C & 0.002 & 0.014 & 0.147 & 0.883 \\
AR 1 & -0.228 & 0.018 & -12.078 & 0.000 \\
AR 2 & -0.120 & 0.019 & -6.243 & 0.000 \\
AR 3 & -0.056 & 0.018 & -2.985 & 0.000 \\
\hline
\end{tabular}

\subsection{Estimating GARCH Model (Kesaveh Company)}

After variance imbalance test and observing imbalance variance among remained main research variables, we find out that ARCH and GARCH model in this research is suitable. By using trial and error test and studying different type of ARCH model we find out that among these models, the GARCH $(1,1)$ model in compliance with different criterions such as AIC, SBIC, HQIC, R2 are the most suitable models; since, there are AIC, SBIC and HQIC. In addition they hold the highest amount of R2

$$
\begin{gathered}
R_{t}=c(1)+c(2) R_{t-1}+c(3) R_{t-2}+c(4) R_{t-3}+e_{t} \quad e_{t} \approx N\left(0, h_{t}\right) \\
h_{i, t}=\alpha_{i, 0}+\alpha_{i, 1} u^{2}{ }_{i, t-1}+\beta_{i, 1} h_{i, t-1}+e_{t}
\end{gathered}
$$

In Table 4 results of estimating model GARCH by using Eviews 7 software is obtained.

Table 4. Results of estimating GARCH model (Kesaveh Co.)

\begin{tabular}{ccccc}
\hline Symbol of variable & Coefficient & Standard Deviation & Z statistics & Probability \\
\hline C & 0.0309 & 0.012 & 2.48 & 0.13 \\
AR 1 & -2.203 & 0.024 & -8.252 & 0.000 \\
AR 2 & -0.068 & 0.026 & -2.645 & 0.008 \\
AR 3 & -0.033 & 0.025 & -1.317 & 0.018 \\
C & 0.159 & 0.007 & 21.709 & 0.000 \\
RESID (-1) & 0.164 & 0.009 & 16.985 & 0.000 \\
GARCH (-1) & 0.699 & 0.011 & 61.525 & 0.000 \\
\hline
\end{tabular}

\subsection{Hypothesis Test}

The third hypothesis mentions that influence of transaction of non-institutional investors on rising magnet effect for price of stock toward price limit is more than transaction of institutional investors. In order to study this issue it is required to consider absolute value of magnet effect for each of the investors and each of them is higher, it has more influence for magnet effect.

Table 5. Results of study for influence of dealers on magnet

\begin{tabular}{lc}
\hline Name of company & Result \\
\hline Kesaveh & Institutional influence is higher than non-institutional \\
\hline
\end{tabular}

Table 6. Results of research by studying influence of dealers on magnet effect

\begin{tabular}{ll}
\hline Name of company & Result \\
\hline Betras & Institutional influence is higher than non-institutional \\
North Excavation & Institutional influence is higher than non-institutional \\
Sina & Institutional influence is higher than non-institutional \\
Fasmin & Institutional influence is higher than non-institutional \\
Foulad & Institutional influence is higher than non-institutional \\
Gheshkar & Influence of non-institutional is more than institutional \\
\hline
\end{tabular}




\begin{tabular}{ll}
\hline Gheshina & Institutional influence is higher than non-institutional \\
Kermasha & Institutional influence is higher than non-institutional \\
Sapa & Institutional influence is higher than non-institutional \\
Sakht & Institutional influence is higher than non-institutional \\
Sepah & Institutional influence is higher than non-institutional \\
Sandough & Institutional influence is higher than non-institutional \\
Maaden & Institutional influence is higher than non-institutional \\
\hline
\end{tabular}

According to the aforesaid table, it is concluded that except one company among all of the companies the influence of institutional dealers on magnet effect and price limit is more than dealers of non-institutional investors. Therefore, institutional and legal investors play more effective role on magnet effect than non-institutional investors.

\section{Conclusion}

In this research first of all the price limit and its influences and aspects were studied and then we examined the effect of price limit on magnet effect. In fact, magnet effect means if the price distance with price limit is more near to zero, the probability of reaching price to the price limit is higher. In the next step, by using 5 minutes time series of sample companies, the ARMA model for each company was created separately and in continuation the GARCH model by using ARMA model was introduced and finally the main models of article were executed and we examined the hypothesis. Results of hypothesis test for available samples at Tehran stock exchange in the year 2012 show that there is magnet effect in Tehran stock exchange i.e., through approaching stock price to the price limit the rate of stock from this limit is higher. Studied performed on 24 companies including (Kesaveh, Ghalrest, Shomal Excavation, Betras, Khazamia, Khasapa, Sefars, Sina, Fazer, Fasmin, Ghapira, Ghanisha, Kermasha, Koravi, Vitro, Sapa, Sakht, Sepah, Sandogh, Lesapa, Melat and Madan) reveal that except one case (Gheshkar) in all of the companies the role of institutional investors on magnet effect is higher than non-institutional investors i.e. role of non-institutional and legal investors on rising magnet effect is more than institutional and legal investors that is warning for senior managers of capital market and legislators that activities of this group of investors are supervised and controlled.

\section{References}

Berkman, H., \& Steenbeek, O. W. (1998). The influence of daily price limits on trading in nikkei futures. $\begin{array}{lllll}\text { Journal of } & \text { Futures } & \text { Markets, } & \text { 265-279. }\end{array}$ http://dx.doi.org/10.1002/(SICI)1096-9934(199805)18:3<265::AID-FUT2>3.0.CO;2-I

Bohl, M. T., \& Brzeszczynski, J. (2006). Do institutional investors destabilize stock prices? Evidence from an emerging market. Journal of International Financial Markets, Institutions and Money, 16(4), 370-383. http://dx.doi.org/10.1016/j.intfin.2005.05.005

Bohl, M., Brzezcynski, J., \& Wilfling, B. (2009). Institutional investors and stock returns volatility: Emperical evidence from a natural experiment. Journal of Financial Stability, 5(2), 170-182. http://dx.doi.org/10.1016/j.jfs.2008.02.003

Chan, L. K. C., \& Lakonishok, J. (1995). The behavior of stock prices around institutional trades. Journal of Finance, 50(4), 1147-1174. http://dx.doi.org/10.1111/j.1540-6261.1995.tb04053.x

Cho, D. D., Russell, J., Tiao, G. C., \& Tsay, R. (2003). The magnet effect of price limits: Evidence from high-frequency data on Taiwan stock exchange. Journal of Empirical Finance, 10, 133-168. http://dx.doi.org/10.1016/S0927-5398(02)00024-5

Du, Y., Liu, Q., \& Rhee, S. G. (2005). An anatomy of the magnet effect: Evidence from the Korea stock exchange high-frequency data. University of Hawaii.

Goldstein, M. A., \& Kavajecz, K. A. (2004). Trading strategies during circuit breakers and extreme market movements. Journal of Financial Markets, 7, 301-333. http://dx.doi.org/10.1016/j.finmar.2003.11.003

Goodfellow, C., Bohl, M. T., \& Gebka, B. (2009). Together we invest? Individual and institutional investors' trading behavior in Poland. International Review of Financial Analysis, 18, 212-221. http://dx.doi.org/10.1016/j.irfa.2009.03.002

Hsieh, P. H., Kim, Y. H., \& Yang, J. J. (2009). The magnet effect of price limits: A logit approach. Journal of Empirical Finance, 16, 830-837. http://dx.doi.org/10.1016/j.jempfin.2009.06.002 
Hsieh, S. F. (2013). Individual and institutional herding and the impact on stock returns: Evidence from Taiwan stock market. International Review of Financial Analysis. http://dx.doi.org/10.1016/j.irfa.2013.01.003

Kim, K. A., \& Ghonrhee, S. (1997). Price limit performance: Evidence from the Tokyo stock exchange. The Journal of Finance, 52(2), 885-901. http://dx.doi.org/10.1111/j.1540-6261.1997.tb04827.x

Kim, K. A., \& Park, J. (2010). Why do price limits exist in stock markets? A manipulation-based explanation. European Financial Management, 16(2), 296-318. http://dx.doi.org/10.1111/j.1468-036X.2008.00456.x

Kim, Y. H., \& Yang, J. J. (2008). The effect of price limits on intraday volatility and information asymmetry. Pacific-Basin Finance Journal, 16, 522-538. http://dx.doi.org/10.1016/j.pacfin.2007.11.002

Lee, B. S., Li, W., \& Wang, S. S. (2010). The dynamics of individual and institutional trading on the Shanghai stock exchange. Pacific-Basin Finance Journal, 18, 116-137. http://dx.doi.org/10.1016/j.pacfin.2009.09.002

$\mathrm{Ng}$, L., \& Wu, F. (2007). The trading behavior of institutions and individuals in Chinese equity markets. Journal of Banking \& Finance, 31, 2695-2710. http://dx.doi.org/10.1016/j.jbankfin.2006.10.029

Ren, F., \& Zhong, L. X. (2012). The price impact asymmetry of institutional trading in the Chinese stock market. Physica A, 391, 2667-2677. http://dx.doi.org/10.1016/j.physa.2011.12.049

Sias, R. W., \& Starks, L. T. (1997). Return autocorrelation and institutional investors. Journal of Financial Economics, 46, 103-131. http://dx.doi.org/10.1016/S0304-405X(97)00026-3

Subrahmanyam, A. (1994). Circuit breakers and market volatility: A theoretical perspective. The Journal of Finance, 49(1), 237-254. http://dx.doi.org/10.1111/j.1540-6261.1994.tb04427.x

Tooma, E. A. (2011). The magnetic attraction of price limits. International Journal of Business, 16(1).

Wong, W. K., Chang, M. C., \& Tu, A. H. (2009). Are magnet effects caused by uninformed traders? Evidence from Taiwan stock exchange. Pacific-Basin Finance Journal, 17(1), 28-40. http://dx.doi.org/10.1016/j.pacfin.2008.03.001

\section{Copyrights}

Copyright for this article is retained by the author(s), with first publication rights granted to the journal.

This is an open-access article distributed under the terms and conditions of the Creative Commons Attribution license (http://creativecommons.org/licenses/by/3.0/). 